\title{
THE EFFECTS OF READING METHOD ON THE COMPREHENSION PERFORMANCE OF THIRD SEMESTER STUDENTS OF BALIKPAPAN FOREIGN LANGUAGE ACADEMY
}

\author{
Muhammad Rochman \\ ABA Balikpapan \\ muhroc@gmail.com
}

\begin{abstract}
In this study the researcher investigated the relative effects of different reading methods on the comprehension performance of Balikpapan Foreign Language Academy EFL Third Semester students. The scores of participants who read three comparable passages in three ways (oral, silent and subvocalizing) were compared. Results revealed a significant difference between oral reading and subvocalization, and between oral reading and silent reading. Oral reading had the greatest effect on comprehension performance among the three reading methods examined. All groups reported that oral reading was the most preferred reading method with the majority of respondents feeling the style best supported comprehension. Feedback suggested that oral reading was preferred specifically because it helps in memorizing words and texts, concentration, and practicing and pronouncing words for real world encounters. It is recommended that second language lecturers and students use all available reading methods in order to identify which method best serves their study objectives.
\end{abstract}

Keywords: Oral reading, silent reading, sub-vocalization, reading comprehension, methods of reading

(C) Pendidikan Bahasa Inggris FPISH IKIP BU Malang

\section{Introduction}

Reading ability has always been viewed as critical to academic success (Bernhardt, 1991; Carrell, 1991; Grabe \& Stoller, 2002; Urquhart \& Weir, 1998). Researchers investigating reading have attempted to look for components that affect reading performance as well as reading behaviors, such as oral reading, that distinguish proficient from less-proficient readers. Oral reading is often viewed as a dated methodology and discouraged by EFL/ESL teachers (Amer, 1997). While some researchers hold the opinion that oral reading is a way of wasting class time (Hill \& Dobbyn, 1979), other scholars (Cho \& Choi, 2008; Gibson, 2008; Rennie, 2000; Reutzel, Hollingsworth, \& Eldredge, 1994; White, 1982) point to potential benefits that can be gained from various oral reading techniques that allow for oral proofreading, pronunciation practice, and conversational fluency.
For decades, investigators have emphasized the importance of oral reading to children in first language teaching situations not only as a means of encouraging children to read, but also of improving their reading comprehension (Alshumaimeri, 2005; Grabe, 1991; Jackson \& Coltheart, 2001; Juel \& Holmes, 1981; McCallum, Sharp, Bell, \& George, 2004; Prior \& Welling, 2001; Rowell, 1976). According to AlQurashi, Watson, Hafseth, Hickman, \& Pond (1995), in second language learning situations oral reading is the best way to teach pronunciation and word recognition during the early stages of second/foreign language acquisition, but reading comprehension is better strengthened by reading silently. Reading silently has traditionally been viewed as the only way to train pupils to read on their own (Al-Qurashi et al., 1995). The underlying principle governing this viewpoint is that reading is normally a solitary activity best done 
in total silence without interruption for best concentration (Al-Qurashi et al., 1995). While researchers continue to explore the effectiveness of oral reading on both language acquisition and comprehension, many questions remain unanswered.

Research on first language learning indicates that people often comprehend better after reading silently (Bernhardt, 1983; Leinhardt, Zigmond, \& Cooley, 1981; Wilkinson \& Anderson, 1995). However, other studies (Teng, 2009) suggest comprehension scores do not differ significantly between silent and oral reading. Further research on the relationship between reading methods and reading comprehension is needed in order to enhance EFL teaching methodologies and to improve learning outcomes. This research furthers understanding of the relationship between reading method and comprehension. As such, results will benefit educational institutions and the EFL researchers, lecturers and students that support them.

\section{Oral vs. Silent Reading Methods}

Reading is a crucial skill in learning and communication. Current trends in education consider reading lessons to be an important early step in the development of mental and linguistic abilities. Reading methods include reading silently, reading using subvocalization (forming the sounds of the words while reading silently), and reading orally to oneself.

Reading silently means reading without labial movements or the vibration of vocal cords. This method implies that graphic forms are visually perceived and then transformed into meanings and ideas without passing through the vocal stage. Silent reading is usually seen as natural reading behavior and for decades has been associated with the idea of reading for comprehension.
As reviewed by Rennie (2000), academic work on reading pedagogy in the first half of the 20th century described the advantages, disadvantages and processes associated with both oral and silent reading (Chall, 1967; Russell, 1949). Although Russell (1949) found that in some places there was a system of reading called 'non-oral' which did not include oral reading instruction at any point in a child's reading development, most scholars agreed by the midtwentieth century that both oral and silent reading activities were necessary for effective reading instruction.

Although the importance of oral reading to children learning a native language is widely accepted, the effectiveness of oral reading in second language classrooms continues to be debated. In her study of oral reading practices in the classroom, Gibson (2008) found that teachers and learners were using oral reading in a variety of ways. The primary reasons for using the method were for practicing pronunciation and intonation. Other reasons included for speaking practice, making graphemic-phonemic connections, diagnosing pronunciation problems, improving fluency and practicing reading skills. In the case of second language learning, Gibson (2008) also found that $82 \%$ of autonomous learners read orally to themselves as part of private study. Asian learners, in particular, commented that oral reading was especially important to them for practicing pronunciation.

\section{Oral Reading and Comprehension}

Hannon and Daneman (2001) proposed four primary processes in reading comprehension: accessing relevant knowledge from long-term memory, integrating accessed knowledge with information from the text, making inferences based on information in the text, and recalling 
newly learned text material. In schema theory, a predominant theory of reading comprehension, reading comprehension is viewed as the process of interpreting new information and assimilating this information into memory structures (Anderson \& Pearson, 1984; Teng, 2009).

As suggested by Teng (2009), differences in native languages can affect second language (L2) oral reading for EFL learners. Reading in a second language requires more cognitive capacity for word identification than reading in one's native language (L1). Slower readers must employ greater cognitive resources than good readers in order to accomplish word recognition. Taguchi and Gorsuch (2002) found that while L1 readers tend to focus more on content words, L2 readers focus equally on content words and grammatical function words. As such, the limited cognitive capacity L2 readers allocate to word recognition tasks may impair their comprehension.

In her study of EFL students, Amer (1997) states that oral reading by the teacher helps readers discover units of meaning that arise from multi-word phrases rather than meaning that is derived from individual words. Oral reading also helps readers to see text as a whole with various levels of meaning rather than as a dissectible passage of graphic cues. Amer suggests that, with appropriate practice, students will gradually begin to realize that a higher level of comprehension can be achieved by reading larger meaningful units of texts. Oral reading performed by the teachers can additionally reinforce correct understanding of punctuation and intonation further strengthening student comprehension.

In researching the relevance of oral reading fluency to reading comprehension, Saiegh-Haddad (2003) conducted a study with 22 Arabic and 28
Hebrew native speakers, 19-25 years old, enrolled in intermediate EFL courses. By analyzing participant's oral reading skill with two texts, one in the participant's native language and one in English, the researchers aimed to determine if there was a difference in the relationship between oral reading skill and reading comprehension. Although there was no relationship found between oral reading fluency and reading comprehension in either Arabic or Hebrew reading (Saiegh-Haddad, 2003), in English, participants with oral reading fluency were found to have better reading comprehension.

Possible explanations for the above finding can be found in a study conducted by Miller and Smith (1985). Conducting a study on comprehension after reading orally and silently, Miller and Smith (1985) tested 94 second to fifth graders who read either at a low level, medium level, or high level. The results suggest that poor readers are better at comprehending when reading orally as compared to reading silently, and are more adept at answering inferential questions than they are at answering literal questions (Miller \& Smith, 1985). Average readers in Miller and Smith's (1985) study read silently more proficiently than poor readers and were able to answer inferential and literal questions equally well. Good readers were found to be proficient at both oral and silent reading and best able to answer literal questions (Miller \& Smith, 1985). The results of Miller and Smith's (1985) study suggest not only that literal comprehension is the best indicator of reading competence, but also that poor readers do benefit from the use of oral reading in the classroom.

In Taiwan, Teng (2009) studied the relationship between reading comprehension and reading methods and learning styles of EFL 12th grade male students. Teng (2009) found that most 
students can benefit from both silent and oral reading activities. Being that some students in the study benefited more from oral reading than others, Teng suggests that EFL teachers be more flexible in selecting various reading methods for use in the classroom setting. Teachers could support a mixture of oral and silent reading assignments that would allow students to engage in their preferred style.

Second language readers often read slowly and have under-developed oral production when compared to native speakers. Oral reading practice was found by Taguchi and Gorsuch (2002) to be more effective than other reading methods at increasing reading speed and comprehension among beginning L2 readers. However, Taguchi and Gorsuch (2002) were doubtful that oral reading of passages can be effective for older L2 readers as they read orally less often and may be less comfortable with the method.

\section{Oral Reading, Culture and Environment}

The viewpoint that oral reading has limited benefit to learners does not take into account the differing social and cultural backgrounds of students. As mentioned previously, there is an enduring opinion that readers who read silently comprehend the most because they both read and think. However, this view implies that students are incapable of thinking while reading orally. It might be more accurate to say that a student's attenuation to the social environment in which she is reading would have a greater bearing on her ability to concentrate than her inability to do both at once.

Alshumaimeri (2005) argues that oral reading is not necessarily a faulty reading method as suggested by Nuttall (1996, but, rather, is an effective aid to comprehension. In a study conducted by
Alshumaimeri, oral reading was found to be used not only for decoding and relating written symbols to sounds, but also for comprehension. The criteria for effective reading comprehension included familiarity or comfortableness with the reading method, which aided the reader's speed of comprehension. Some informants in Alshumaimeri's study stated they would read orally when they were studying, which requires concentration, memorization, and comprehension, and would read silently when they read for enjoyment.

Furthering the body of work on L2 reading methods, this study investigates the effects of different reading methods on L2 student reading comprehension. The research questions are as follows: do different reading methods affect the comprehension of Balikpapan Foreign Language Academy students; which reading methods affect reading comprehension; and which reading methods do Balikpapan Foreign Language Academy students prefer and why?

\section{Research Method}

This research employs a classroom-based, quasi-experimental design in order to examine the effects of different reading methods on the comprehension performance of Balikpapan Foreign Language Academy students.

In educational research, a quasiexperiment is more commonly used due to fixed school schedules and logistical problems (Cohen, Manion, \& Morrison, 2007). The different reading methods studied were oral, subvocalization, and silent reading. Comprehension performance was determined from the students' comprehension scores on multiple-choice tests. In order to minimize the effects of repetition, three different passages were selected from 
McCall-Crabbs Standard Test Lessons in Reading, Book D (1979).

Each group read each passage using one of the three reading methods (oral, subvocalization, and silent). The study participants always read passage 1 first, and then passages 2 and 3 . However, in order to counterbalance the design of the study, the order of the reading method was rotated. For example, Group 1 read passage 1 orally, passage 2 using subvocalization, and passage 3 silently, while Group 2 read passage 1 using subvocalization, passage 2 silently, and passage 3 orally. In this way, the effect of passage difficulty or type of passage reading was minimized with regard to measuring the reading comprehension performance of the study students.

Each group was located in a different room during testing. The noise level during oral reading was not perceived as a distraction to comprehension as students read softly and the testing rooms were large. After reading each passage and taking the reading test for that passage, the students were asked to fill out a feedback slip asking about their preferred reading method and the reason behind their preference.

\section{Participants}

Participants in the study were 145 Balikpapan Foreign Language Academy students with an average age of 19-25 years, in the second year (Third Semester) in a Balikpapan Foreign Language Academy in Balikpapan. Like most Balikpapan Foreign Language Academy students they had studied English for three years, since the 1st semester. Participating students were expected to be fairly representative of the target population of Balikpapan Foreign Laguange Academy learners in terms of ability, interest, and age. However, one should acknowledge the limitation of drawing students from one school in Balikpapan. The participating students were distributed by the school management into four classes with the intention that each class should be a balanced mixed-ability class. The students' level of language proficiency was considered to be A1 level of the European framework.

\section{Passages}

Three expository passages were selected from McCall-Crabbs Standard Test Lessons in Reading, Book D (1979). Each passage was followed by five questions, posed in English, with four-option multiple choice answers. Multiple choice questions are perhaps the most commonly used format in standardized reading comprehension tests. The procedure's advantages lie in the simplicity of its scoring (Koda, 2005). Passage one, A School Charity Day, contains 141 words and describes a fundraising bazaar held at a children's school. The second passage, The Best Way to Lose Weight, contains 139 words and provides advice on how to lose weight. The third passage, A Carpenter Story, contains 108 words and describes how one person became a carpenter. A reliability analysis was computed for each test using test/retest method (Cohen, Manion, \& Morrison, 2007). The reliability results were (Pearson coefficient) 0.7462 for the first passage, 0.6715 for the second passage, and 0.6605 for the third passage. Reliability was deemed sufficient given that the test only contained five items.

\section{Feedback Slips}

The feedback slip was a small piece of paper that was given to each student after completing each reading test (three feedback slips were collected per participant). It included three questions that asked students to write down (in L1) if the reading method they 
used supported their comprehension, to rank which reading methods they generally prefer, and to explain their choices. The purpose of the feedback slips was to help in understanding the effects of the different reading methods and to know which reading methods students prefer in everyday life. The number of responses collected was 227 out of 435 feedback slips distributed with a return rate of $52.2 \%$. The low rate of return is believed to be because the slips were distributed after each test. Some students returned the feedback slips blank because they had answered the question on the first slip and did not change their views. The slips were distributed after each test in order to provide equal opportunity for students to reflect on each reading method.

\section{Procedure}

The research was conducted on a regular school day during the extracurricular activity time (the last two periods of one day per week). The available time for testing was 110 minutes. Each reading test was allocated 20 minutes followed by 5-7 minutes for filling out the feedback slips. The students were randomly assigned to their group. As described above, each group read a passage using each of the three different reading methods. All students were told to read the reading instructions carefully and to ask for clarification if needed.

There were three lecturers, one for each group, who helped administer the tests and explained the procedure clearly. Needed materials were prepared beforehand and placed in envelopes according to the study design. The researcher supervised the administration by moving from one room to another to check that the procedures were followed according to plan and to answer any questions.
The data collected consisted of the comprehension scores obtained from the five multiple-choice questions designed for each of the three passages as well as the data collected from the feedback slips. The data analysis was conducted in accordance with the research questions, all of which were concerned with comprehension performance as measured by the scores from the multiple-choice questions, the dependent variable. A one-way analysis of variance (ANOVA) was used to test the differences between the reading methods and a post-hoc analysis using the Scheffe test was conducted to locate the source of differences. Then, two-way ANOVA was used to test the differences between the groups with different reading methods. The study results are reported below.

\section{Results}

The results obtained are presented in accordance with the research questions, beginning with the first research question. In order to answer the first research question (Do different reading methods affect the comprehension of Balikpapan Foreign Language Academy students?) a oneway analysis of variance (ANOVA) test was conducted with the post-hoc Scheffe test. There was a significant difference at level 0.01 between the Balikpapan Foreign Language Academy students in comprehension performance according to the reading method. A significant difference was found between oral reading and subvocalization (mean difference 1.92, $\mathrm{p}<0.01$ ), and between oral reading and silent reading (mean difference 2.32, $\mathrm{p}<0.01$ ). The largest mean occurred for oral reading (9.65), which had the greatest effect on comprehension performance among the three reading methods included in the study.

To answer the second research 
question, the data obtained from the feedback slips show the students' responses to the question (Does this reading method assist you in understanding this passage?). The results show that $57 \%$ of the students thought that oral reading helped them better comprehend the passage; whereas 26.2\% and $17.9 \%$, respectively, thought silent reading and subvocalization helped them understand the passage. The reading method that had the greatest positive effect on comprehension was oral reading with a mean value 9.65. Subvocalization and silent reading had

mean values of 7.72 and 7.33, respectively. These results indicate that oral reading helped students better understand passages.

To answer the third research question (Which reading methods do Balikpapan Foreign Language Academy students prefer and why?), the results obtained from the feedback slips show the ranked order of the preferred reading style of each group as well as an explanation of their choice of order. Of all groups, $50.57 \%$ of students reported that oral reading was the most preferred reading method. Subvocalization was ranked second with $22.76 \%$, whereas silent reading was third with $14.02 \%$.

Data obtained from the feedback slips is summarized in Tables $1 \mathrm{a}, 1 \mathrm{~b}$, and 1c and indicate the reason the students preferred each method of reading. The rate of return $(52.2 \%)$ of the feedback slips could indicate that the reason for preferring a reading method is static and that the learners felt they did not need to provide the same feedback after each passage. The results are presented according to each reading method
Table 1a: The Students' Responses for Reasons for Preferring Oral Reading.

\begin{tabular}{|l|l|l|l|}
\hline $\begin{array}{l}\mathrm{N} \\
\mathrm{o}\end{array}$ & Students justification & $\begin{array}{l}\text { Freque } \\
\text { ncy }\end{array}$ & $\begin{array}{l}\text { Percenta } \\
\text { ge }\end{array}$ \\
\hline 1 & $\begin{array}{l}\text { It helps in memorizing and } \\
\text { remembering new words }\end{array}$ & 26 & $20.63 \%$ \\
\hline 2 & $\begin{array}{l}\text { I use this way for studying as it } \\
\text { helps me understand and } \\
\text { memorize the text }\end{array}$ & 25 & $19.84 \%$ \\
\hline 3 & $\begin{array}{l}\text { It makes me concentrate more } \\
\text { and understand the text }\end{array}$ & 20 & $15.9 \%$ \\
\hline 4 & $\begin{array}{l}\text { In reading aloud it helps me } \\
\text { understand more as I use three } \\
\text { senses (sight, hearing, and } \\
\text { speech }\end{array}$ & 15 & $11.9 \%$ \\
\hline 5 & $\begin{array}{l}\text { It helps in pronunciation practice } \\
\text { and pronouncing the words } \\
\text { better }\end{array}$ & 13 & $10.32 \%$ \\
\hline 6 & $\begin{array}{l}\text { It makes the words more } \\
\text { familiar and helps memorizing } \\
\text { them and using them in } \\
\text { conversations with others }\end{array}$ & 12 & $9.52 \%$ \\
\hline 7 & $\begin{array}{l}\text { I read faster and understand } \\
\text { more in reading aloud }\end{array}$ & 13 & $10.32 \%$ \\
\hline 8 & $\begin{array}{l}\text { It helps in conversation and } \\
\text { practice talking in a foreign } \\
\text { language }\end{array}$ & 12 & $9.52 \%$ \\
\hline & TOTAL & 126 & $100 \%$ \\
\hline
\end{tabular}

Table 1b: The Students' Responses for Reasons for Preferring Silent Reading

\begin{tabular}{|l|l|l|l|}
\hline No & Students justification & $\begin{array}{l}\text { Freque } \\
\text { ncy }\end{array}$ & $\begin{array}{l}\text { Percenta } \\
\text { ge }\end{array}$ \\
\hline 1 & $\begin{array}{l}\text { I read silently for leisure not for } \\
\text { study }\end{array}$ & 11 & $29.73 \%$ \\
\hline 2 & $\begin{array}{l}\text { It helps me understand and } \\
\text { concentrate more }\end{array}$ & 10 & $27.03 \%$ \\
\hline 3 & $\begin{array}{l}\text { I read faster and understand } \\
\text { more }\end{array}$ & 6 & $16.22 \%$ \\
\hline 4 & $\begin{array}{l}\text { I don't like annoying other } \\
\text { people when I read aloud }\end{array}$ & 5 & $13.51 \%$ \\
\hline 5 & $\begin{array}{l}\text { I feel more relaxed when I read } \\
\text { silently }\end{array}$ & 5 & $13.51 \%$ \\
\hline & TOTAL & 37 & $100 \%$ \\
\hline
\end{tabular}


Table 1c: The Students' Responses for Reasons for Preferring Subvocalization

\begin{tabular}{|l|l|l|l|}
\hline $\begin{array}{l}\mathrm{N} \\
\mathrm{o}\end{array}$ & Students justification & $\begin{array}{l}\text { Freque } \\
\text { ncy }\end{array}$ & $\begin{array}{l}\text { Percent } \\
\text { age }\end{array}$ \\
\hline 1 & $\begin{array}{l}\text { It makes me concentrate } \\
\text { more and understand the text }\end{array}$ & 15 & $23.43 \%$ \\
\hline 2 & I use this way for studying & 15 & $23.43 \%$ \\
\hline 3 & $\begin{array}{l}\text { I do not annoy other people } \\
\text { and concentrate than reading } \\
\text { silently }\end{array}$ & 11 & $17.2 \%$ \\
\hline 4 & $\begin{array}{l}\text { It helps in memorizing and } \\
\text { remembering new words }\end{array}$ & 10 & $15.63 \%$ \\
\hline 5 & $\begin{array}{l}\text { It helps in pronunciation } \\
\text { practice and pronouncing the } \\
\text { words better }\end{array}$ & 7 & $10.94 \%$ \\
\hline 6 & $\begin{array}{l}\text { I read faster than reading } \\
\text { aloud and keep my } \\
\text { concentration }\end{array}$ & 6 & $9.37 \%$ \\
\hline & TOTAL & 64 & $100 \%$ \\
\hline
\end{tabular}

Table 1a shows that just over $40 \%$ of the respondents preferred oral reading because it was perceived as aiding in memorizing and remembering new words. Using oral reading as a means to improve conversational English or improve pronunciation was not a common justification among respondents. The usefulness of oral reading in improving conversational English was the least cited justification with only $5.5 \%$ of respondents choosing it as their primary reason for preferring oral reading.

As seen in Table 1b, nearly $30 \%$ of respondents indicated that they read silently for leisure, but not for study in justifying their preference for silent reading. Such a result indicates that students associate silent reading with leisure reading and oral reading with language studies. Many students, 27\%, also indicated that understanding and concentration were heightened when reading silently. Anxiety about annoying others and greater relaxation while reading silently were less cited reasons for preferring silent reading $(13.5 \%$ and $13.5 \%$, respectively).

Respondents with a preference for subvocalization cited the justifications of enhanced concentration and preferred method of studying ( $23.4 \%$ and $23.4 \%$, respectively) as seen in Table 1c. Such results indicate subvocalization is a study habit perceived as enhancing students' ability to concentrate on text while studying. As in the results presented in Table 1a summarizing the justifications for preferring oral reading, pronunciation was not an often cited reason for employing subvocalization as a reading method (10.9\%).

A one-way ANOVA with post-hoc Scheffe test was used to explore the relationship between the preferred reading method and the comprehension performance of the students. A significant relationship was found between the preferred reading method and the students' comprehension performance, $(F=5.919$, Sig. $=.001)$. A significant difference was found in favor of the students who prefer oral reading over reading using subvocalization or silent reading (mean value 8.96 ). The results suggest that there is a relationship between the selected reading method and the comprehension performance of the Balikpapan Foreign Language Academy students.

To evaluate if there is a significant difference between groups with regard to comprehension performance regardless of reading method, a two-way ANOVA was conducted. The results indicate three things: the differences between the groups, regardless of reading methods, were not significant; the differences based on reading methods were significant; and the interaction effects between groups and reading methods were significant.

\section{Discussion}

In summary, the study of the relative effects of different reading methods on the comprehension performance of Balikpapan Foreign Language Academy EFL Third Semester students shows that there is a significant 
difference between the Balikpapan Foreign Language Academy students in comprehension performance according to reading method. These results support the literature suggesting oral reading can be a beneficial reading method when used in the L2 classroom (Cho \& Choi 2008; Gibson, 2008; Rennie, 2000; Reutzel, Hollingsworth, \& Eldredge, 1994; White, 1982). If reading comprehension can be defined as the process of interpreting new information and assimilating this information into memory structures as schema theory suggests, this study indicates that oral reading aids comprehension by improving students' ability to concentrate and memorize new words.

In this study there was a significant difference between oral reading and subvocalization in regard to comprehension and between oral reading and silent reading. Oral reading had the greatest positive effect on comprehension performance among the three reading methods included in the study. As found in the literature, students exposed to oral reading techniques in L2 classrooms report improved comprehension of reading material (Amer, 1997; Saiegh-Haddad, 2003; Warwick \& Mangubhai, 1983). Although it should be reiterated that reading ability was not measured among the participants in this study, all participants were in the same grade and differences in reading ability would presumably have an insignificant impact on the study results.

Despite the negative opinion some scholars hold toward the use of oral reading in the language classroom (Hill \& Dobbyn, 1979), this study demonstrates that oral reading can in fact assist some students in acquiring proficient language comprehension. Oral reading, although often described as an effective method of learning for recognizing and pronouncing words with ease and fluency, was more often cited by the participants in this study as a means of strengthening memorization of new words and effective concentration as well as comprehension. The results of this study are in relation to student performance on a comprehension test and not in relation to language instruction or leisure reading.

Although many students indicated that understanding and concentration are heightened when reading silently, one third of respondents indicated that they read silently for leisure, but not for study. Such a result indicates students associate silent reading with leisure reading and oral reading with language studies. This preference for silent leisure reading supports Nuttall's (1996) opinion that oral reading is uncommon outside the classroom.

With regard to student preference for a particular reading style, all groups reported that oral reading was the most preferred reading method with subvocalization ranked second and silent reading third. These results suggest that most of the students hold the opinion that oral reading is an effective method for understanding the passages. In addition, participants indicated that oral reading was the preferred reading method not only because it helps in memorization and concentration, but it is also helpful for practicing and pronouncing words for real world encounters. This clear preference for oral reading for study purposes is partially due to traditional teaching methods, such as rote learning, that require learners to memorize information.

Respondents with a preference for subvocalization cited the justifications of enhanced concentration and preferred method of studying. Such results indicate subvocalization is a study habit that is perceived as enhancing students' ability to concentrate on text while studying. However, Balikpapan Foreign 
Language Academy students do not seem to support Nuttall's (1996) opinion that subvocalization is an ineffective reading method. Participants in this study preferred subvocalization above silent reading as a reading method.

If Gibson (2008) and Amer (1997) are correct in assuming that oral reading can be made a more effective learning device with greater systemization in the curriculum, the methods by which Balikpapan Foreign Language Academy lecturers encourage and use oral reading in the classroom should be further researched. It is possible that the Balikpapan Foreign Laguange Academy scholastic environment provides an ideal setting for allowing oral reading methods to support significant gains in reading comprehension. This educational setting, coupled with a cultural appreciation for oral religious traditions and memorization through oral recitation, could foster strong tendencies among students to associate oral reading with concentration and memorization.

As reported by Alshuamimeri (2005), one interviewee reported feeling as if oral reading allowed for better understanding and concentration. Further, the respondent suggested that Arabic literature in particular is better appreciated and analyzed when read aloud. Additionally, oral reading makes a strong impression because the reader hears as well as sees what is being read and the sense of hearing is effective in supporting comprehension. Albar (1996) stated the capacity to learn a language is dependent on normal hearing more than any other trait suggesting that someone who reads aloud is more likely to understand what he is reading than someone who reads silently.

\section{Conclusion}

In investigating the relative effects of different reading methods on the comprehension performance of
Balikpapan Foreign Language Academy EFL Third Semester students, the results showed that oral reading had the greatest positive effect on the comprehension performance of the study sample. This study also found that oral reading was the most preferred reading method. Oral reading was perceived by students to aid in memorization and concentration. EFL lecturers can take from this finding that despite the relative inconsistencies in academic findings regarding the effect of reading method on comprehension, some students do in fact find oral reading to be beneficial in the L2 classroom. Although such findings may be culturally or individually specific, greater flexibility in the design of second language teaching methodologies is warranted pending greater research on the subject. Additionally, L2 students should use all available reading methods in order to identify which method best serves their study objectives.

Reading ability is acquired through practice, not through educational settings or teaching methods. When viewed as a continuum with beginners at one end and fluent readers at the other end, a student's growing capacity is defined by his or her ability to rapidly understand and comprehend new lexicon and context. Readers may find that while comprehension is not necessarily bolstered by practicing oral reading methods, memorization and concentration may be enhanced by employing oral reading techniques, either in the classroom or during private study. Unfortunately, the campus library is lacking material for children. Making reading materials available from an early age should be prioritized in order to support a well rounded adult ability to comprehend written language. To further the findings of this study, additional research is needed on L2 learners of different ages and gender. 
References

Albar, M. A. (1996). Human Development. Saudi publishing \& distributing house, Jeddah, Saudi Arabia.

Al-Qurashi, K., Watson, M., Hafseth, J., Hickman, D,. \& Pond, R. (1995). 'English For Saudi Arabia: first year secondary, Teacher's book' .Ministry Of Education Press, Riyad, Saudi Arabia.

Alshumaimeri, Y. (2005). Is reading aloud a faulty habit. Paper presented at the second international

conference: Language, culture and literature, Minia University, Egypt.

Amer, A. (1997). The effect of the teacher's reading aloud on the reading comprehension of EFL students. ELT Journal, 51(1), 4347.

Cho, K.S. \& Choi, D.S. (2008). Are Read-Alouds and Free Reading "Natural Partners"? Busan National University of Education Research Institute, 36(5), 69-73.

Cohen, L., Manion, L., \& Morrison, K. (2007). Research methods in education (Sixth ed.). US: New York:Routledge.

Gibson, S. (2008). Reading aloud: a useful learning tool? ELT Journal, 62(1), 29-36.

Grabe, W. (1991). Current Developments in Second Language Reading Research. TESOL Quarterly, 25(3), 375406.

Grabe, W. \& Stoller, F. L. (2002). Teaching and researching reading. London: Longman.

Hannon, B., \& Daneman, M. (2001). A new tool for measuring and understanding individual differences in the component processes of reading comprehension. Journal of
Educational Psychology,93(1), 103-128.

Jackson, N. \& Coltheart, M. (2001). Routes to reading success and failure. Hove, UK: Psychology Press.

Koda, K. (2005). Insights into second language Reading: A crosslinguistics approach. Cambridge, UK: Cambridge University Press.

McCallum, R. S., Sharp, S., Bell, S. M., \& George, T. (2004). Silent versus oral reading

comprehension and efficiency. Psychology in the Schools, 41(2), 241-246.

Nuttall, C. (1996). Teaching Reading Skills in a Foreign Language. UK: Heinemann.

Prior, S. M., \& Welling, K. A. (2001). "Read in your head": A Vygotskian analysis of the transition from oral to silent reading. Reading Psychology, 22(1), 1-15.

Rennie, J. (2000). Teaching reading: Oral reading practices as a pedagogical tool in the primary school. The Australian Journal of Language and Literacy, 23(3), 197-211.

Reutzel, D. R., Hollingsworth, P. M. \& Eldredge, J. L. (1994). Oral Reading Instruction: The Impact on Student Reading Development. Reading Research Quarterly, 29(1), 40-62.

Saiegh-Haddad, E. (2003). Bilingual oral reading fluency and reading comprehension: The case of Arabic/Hebrew (LI) -English (L2) readers. Reading and Writing: An Interdisciplinary Journal,16(8), 717-736.

Taguchi, E., \& Gorsuch, G. J. (2002). Transfer effects of repeated EFL reading on reading new passages:A preliminary 


\section{Jomingery}

(2019), 1 (2): 28-39

investigation. Reading in a

Foreign Language, 14(1), 43-65.

Teng, Y. (2009). The Relationship of reading methods and learning styles to Taiwanese 12th Grade male students' reading comprehension in English. A Dissertation presented to The Faculty of the School of Education International and Multicultural Education Department. The University of San Francisco.

Urquhart, S. \& Weir, C. (1998). Reading in a second language: Process, product and practice. London: Longman.

Wilkinson, I. A. G., \& Anderson, R. C. (1995). Sociocognitive processes in guided silent reading: A microanalysis of small-group lessons. Reading Research Quarterly, 30(4), 710-740. 